\title{
Immediate effects of nitrogen, phosphorus, and potassium amendments on the methanotrophic activity and abundance in a Chinese paddy soil under short-term incubation experiment
}

\author{
Yong Zheng • Li-Mei Zhang • Ji-Zheng He \\ Received: 13 February 2012 / Accepted: 7 September 2012 /Published online: 25 September 2012 \\ (C) Springer-Verlag 2012
}

\begin{abstract}
Purpose Methane-oxidizing bacteria (methanotrophs) biologically consume and consequently affect the concentration of atmospheric methane $\left(\mathrm{CH}_{4}\right)$, the second most prominent greenhouse gas, and therefore play critical roles in the mitigation of global warming effect. Long-term fertilization often affects the methanotrophic community and $\mathrm{CH}_{4}$ oxidation in various soils. Here, the immediate effects of nitrogen $(\mathrm{N})$, phosphorus $(\mathrm{P})$, and potassium $(\mathrm{K})$ amendments on the $\mathrm{CH}_{4}$ oxidation activity and methanotrophic community structure were evaluated.

Materials and methods Paddy soil samples were collected from the Taoyuan Experimental Station of the Chinese Academy of Sciences in central Hunan Province of China. A laboratory-based incubation experiment was conducted to investigate the immediate effects of $\mathrm{N}, \mathrm{P}$, and $\mathrm{K}$ amendments on the methanotrophs in soil. The $\mathrm{CH}_{4}$ oxidation rates and methanotrophic activities were determined by measuring the dynamic changes of $\mathrm{CH}_{4}$ concentration in the incubation system. The methanotrophic abundance and community changes in all of the seven treatments with and without
\end{abstract}

Responsible editor: Yanfen Wang

Electronic supplementary material The online version of this article (doi:10.1007/s11368-012-0601-2) contains supplementary material, which is available to authorized users.

\section{Y. Zheng}

State Key Laboratory of Mycology, Institute of Microbiology,

Chinese Academy of Sciences,

Beijing 100101, People's Republic of China

Y. Zheng $\cdot$ L.-M. Zhang $\cdot$ J.-Z. He $(\bowtie)$

State Key Laboratory of Urban and Regional Ecology, Research

Center for Eco-Environmental Sciences,

Chinese Academy of Sciences,

Beijing 100085, People's Republic of China

e-mail: jzhe@rcees.ac.cn nutrients addition were studied using real-time PCR and denaturing gradient gel electrophoresis, respectively.

Results and discussion All of the N, P, and $\mathrm{K}$ treatments significantly decreased the $\mathrm{CH}_{4}$ oxidation activities. Compared with the control, the $\mathrm{P}$ and $\mathrm{K}$ amendments significantly increased the methanotrophic population size, but the $\mathrm{N}$ treatments have no effect on the methanotrophic abundance. A negative correlation was found between methanotrophic activity and methanotrophic abundance. We suggested that methanotrophic activity may not be inferred through the pmoA gene copies, especially in the short-term simulation experiments. Investigation of the methanotrophic population size and diversity is not enough to evaluate the soil $\mathrm{CH}_{4}$ sink accurately.

Conclusions We concluded that the additions of N, P, and K reduce the activity but enhance the abundance of methanotrophs in a Chinese paddy soil through a short-term incubation experiment. Additionally, we found that the $\mathrm{CH}_{4}$ oxidation activity could be completely inhibited by $\mathrm{Cl}^{-}$ toxicity. Our results implied that caution should be exercised in the types and amounts of fertilizers, especially $\mathrm{KCl}$ in agricultural systems to control the instantaneous increase in $\mathrm{CH}_{4}$ emission from the field.

Keywords Chloride toxicity $\cdot$ Fertilizer $\cdot$ Methane oxidation $\cdot$ Methanotrophs $\cdot$ Nutrient element $\cdot$ pmoA . Real-time PCR

\section{Introduction}

Soils are an important sink in the global budget of atmospheric methane $\left(\mathrm{CH}_{4}\right)$, which is the second most prominent greenhouse gas, contributing roughly $20 \%$ to the observed global warming (IPCC 2007). Methane-oxidizing bacteria 
(methanotrophs), which are ubiquitous in various soils (Bodelier et al. 2000; Reay and Nedwell 2004; Zhou et al. 2008a, b; Kolb 2009; Zhang et al. 2010; Semrau 2011; Lü et al. 2012; Zheng et al. 2012), can consume $\mathrm{CH}_{4}$ with oxygen to produce $\mathrm{CO}_{2}$ for energy generation, and they utilize the $\mathrm{CH}_{4}$ carbon for generating new biomass (Conrad and Donald 2007). Methanotrophs are obligate aerobes and are classified into two groups (types I and II) differing in physiology, phylogeny, morphology, and biochemistry characteristics (Hanson and Hanson 1996). Given their critical roles in buffering the global warming effect, a growing body of research is targeting the methanotrophic community structure, their $\mathrm{CH}_{4}$ oxidation activity, and their responses to environmental factors (Le Mer and Roger 2001; Dumont et al. 2006; Kolb 2009; Bodelier 2011; Zheng et al. 2012).

The ecological distribution, diversity, and $\mathrm{CH}_{4}$ oxidation activity of methanotrophs are affected by soil characteristics, such as $\mathrm{pH}$, temperature, moisture, and land use (King 1997; Börjesson et al. 1998; Knief et al. 2003; Horz et al. 2005; Mohanty et al. 2007; Menyailo et al. 2008; Singh et al. 2010; Zheng et al. 2012). Chemical fertilizers have been intensively used globally to meet the growing food demands because of continued population growth (Snyder et al. 2009). However, the use of fertilizers in agricultural systems often negatively affects the potential of soils to act as a $\mathrm{CH}_{4}$ sink, which leads to elevated $\mathrm{CH}_{4}$ concentrations in the atmosphere (Seghers et al. 2005).

As a major nutrient element controlling biological productivity in terrestrial systems, nitrogen $(\mathrm{N})$ also has an important function in $\mathrm{CH}_{4}$ oxidation. However, there is still no consistent point of view concerning methanotrophic communities under $\mathrm{N}$ fertilizer applications. The mainstream viewpoint presents that $\mathrm{N}$ application is inhibitory (Steudler et al. 1989; Hütsch et al. 1994; Reay and Nedwell 2004), whereas other studies reported stimulatory effects (Bodelier et al. 2000; Yang et al. 2011) and no effects on methanotrophs (Dunfield et al. 1995; Dan et al. 2001). On the other hand, phosphorus (P) fertilizers were suggested to have an apparent effect on microbial composition and biomass (He et al. 2008; Liu et al. 2012), as well as on $\mathrm{CH}_{4}$ production and oxidation activity ( $\mathrm{Lu}$ et al. 1999; Conrad and Klose 2005). Furthermore, potassium (K) amendment seems to stimulate the methanotroph population in rice field soil (Babu et al. 2006).

A clear distinction was found between the short- and long-term effects of fertilization (Hütsch 2001). For instance, the short-term application of $\mathrm{N}$ fertilizers results in an immediate inhibition of $\mathrm{CH}_{4}$ consumption because of competition for methane monoxygenase (MMO) (Schimel 2000). In the long-term application, however, $\mathrm{N}$ fertilizers alter the methanotrophic composition, resulting in inhibited $\mathrm{CH}_{4}$ oxidation (Hütsch 2001; Seghers et al. 2005). Many studies have determined the effect of long-term fertilization

on methanotrophs in field conditions (Seghers et al. 2003, 2005; Gulledge et al. 2004; Zheng et al. 2008). However, few reports have assessed the short-term effects of fertilization on methanotrophic activity or community (Jang et al. 2011), especially investigations on methanotrophic activity and communities under short-term nutrient additions.

In the present study, we determined the $\mathrm{CH}_{4}$ oxidation activity of a Chinese paddy soil to the immediate addition of $\mathrm{N}$, $\mathrm{P}$, and $\mathrm{K}$ through a short-term, laboratory-based incubation experiment. The community structure of methanotrophs in the soil incubated was also studied using real-time PCR and denaturing gradient gel electrophoresis (DGGE). The objectives were to detect and compare the immediate effects of $\mathrm{N}, \mathrm{P}$, and $\mathrm{K}$ amendments on $\mathrm{CH}_{4}$ oxidation activity and methanotrophic community structure in a short-time incubation system.

\section{Materials and methods}

\subsection{Experimental soil}

Soil samples $(0-20 \mathrm{~cm}$ in depth) were collected from a nonfertilized plot in a long-term fertilization experimental field at the Taoyuan Experimental Station $\left(28^{\circ} 55^{\prime} \mathrm{N}, 111^{\circ}\right.$ $26^{\prime} \mathrm{E}$ ) of the Chinese Academy of Sciences in central Hunan Province of China. The description of the station is available in Zheng et al. (2008). Soil was sieved through a 2-mm mesh to remove fine roots and large organic debris and was stored at $4{ }^{\circ} \mathrm{C}$ prior to the incubation experiment. The selected soil characteristics are listed in Table 1.

\subsection{Methane oxidation}

The soil incubation experiment was conducted according to the method described by Zheng et al. (2012). Briefly, $22 \mathrm{~g}$ of fresh soil (equivalent to $20 \mathrm{~g}$ dry weight) was transferred into a $250-\mathrm{mL}$ culture serum bottle. An empty bottle (no soil added) served as blank to measure the gas tightness of bottles. Then, $3 \mathrm{~mL}$ of aqueous $\mathrm{N}$ [as $\left(\mathrm{NH}_{4}\right)_{2} \mathrm{SO}_{4}$ and urea],

Table 1 Selected physicochemical properties of the tested soil

${ }^{\mathrm{a}}$ The data of $\mathrm{pH}$, soil organic matter, total nitrogen, available phosphorus, and potassium were reported previously (Zheng et al. 2008)

\begin{tabular}{lc}
\hline Item & Value \\
\hline $\mathrm{pH}\left(\mathrm{H}_{2} \mathrm{O}\right)$ & $4.94^{\mathrm{a}}$ \\
Clay content $(\%)$ & 30.5 \\
Silt content $(\%)$ & 53.5 \\
Sand content $(\%)$ & 16.0 \\
Soil organic matter $(\mathrm{g} / \mathrm{kg})$ & 29.2 \\
Total nitrogen $(\mathrm{g} / \mathrm{kg})$ & 3.53 \\
Available phosphorus $(\mathrm{mg} / \mathrm{kg})$ & 19.1 \\
Available potassium $(\mathrm{mg} / \mathrm{kg})$ & 47.1
\end{tabular}


$\mathrm{P}$ (as $\mathrm{NaH}_{2} \mathrm{PO}_{4}$ and $\mathrm{KH}_{2} \mathrm{PO}_{4}$ ), and $\mathrm{K}$ (as $\mathrm{KCl}$ and $\mathrm{K}_{2} \mathrm{SO}_{4}$ ) was uniformly added into the corresponding bottles using a $10-\mathrm{mL}$ syringe, and the chemicals and soil samples in bottles were carefully mixed by hand. After addition of solutions, the amounts of the N, P, and K were 150,220 , and $332 \mathrm{mg} / \mathrm{kg}$ dry weight, respectively (fertilizer levels were widely adopted in practical agriculture) (Table S1, Electronic supplementary material). Sterilized water $(3 \mathrm{~mL})$ was applied as the zero nutrient control. Each treatment contained 21 culture serum bottles for 7 sampling times. The bottles were sealed with thick butyl rubber stoppers and covered with aluminum caps. All bottles were supplemented with $\mathrm{CH}_{4}$ at an initial concentration of approximately $11 \mu \mathrm{LL}^{-1}$ (ppm) and incubated at $25{ }^{\circ} \mathrm{C}$ in the dark. After incubated for 0,24 (12 for P treatments and its control, the same as below), 48 (36), 96 (60), 144 (108), 240 (204), and 336 (324)h, three culture serum bottles for each treatment were randomly taken out and used for analyzing the $\mathrm{CH}_{4}$ concentrations, respectively.

The $\mathrm{CH}_{4}$ concentration was determined by extracting $1 \mathrm{~mL}$ of gas samples from each bottle and measured using a gas chromatograph (Agilent 6820, Agilent Technologies) equipped with a flame ionization detector. The carrier gas for the chromatograph was $\mathrm{N}_{2}\left(30 \mathrm{mLmin}^{-1}\right)$, and the injector, oven, and detector temperatures were 100, 80, and $180{ }^{\circ} \mathrm{C}$, respectively. The flame gases, including $\mathrm{H}_{2}$ and compressed air, were introduced at 20 and $30 \mathrm{mLmin}^{-1}$, respectively. At the end of incubation, the soil samples at 336 (324)h were collected for DNA extraction and subsequent real-time PCR analysis.

\subsection{DNA extraction}

Soil DNA was extracted using the FastDNA ${ }^{\circledR}$ Spin Kit for Soil according to the manufacturer's instructions. The concentration and quality of the extracted DNA were analyzed through spectroscopic analysis (NanoDrop Technologies). The DNA samples were diluted 10-, 100-, and 1,000-fold to test the possible inhibitory effects of humic substances via PCR. Consequently, the 10 -fold diluted DNA samples (i.e., $10-20 \mathrm{ng} \mu \mathrm{L}^{-1}$ ) were selected as templates.

\subsection{Real-time PCR}

Methanotrophic abundance was analyzed based on the copy numbers of pmoA gene, which encode subunits of particulate methane monooxygenase, using real-time PCR, which was performed on an iCycler iQ5 thermocycler (BioRad). Specific primer pairs A189 and mb661 (Costello and Lidstrom 1999; Holmes et al. 1999) were used to amplify the methanotrophic $p m o A$ gene fragments. Amplification was performed using SYBR ${ }^{\circledR}$ Premix Ex Taq ${ }^{\mathrm{TM}}$, as described by the suppliers (TaKaRa). The detailed real-time PCR assay was performed through the protocols described by Zheng et al.
(2010). All PCR assays were performed at least in triplicate. Data analysis was carried out using iCycler software (version 1.0.1384.0 CR).

\subsection{Denaturing gradient gel electrophoresis}

The extracted DNA was used as templates to produce PCR products for subsequent DGGE. The primers A189-gc and mb661 were selected to amplify the methanotrophic pmoA gene fragment. The composition of the PCR mixtures and the touchdown thermocycling conditions were described previously (Zheng et al. 2008). The PCR products were loaded onto $6 \%(w / v)$ polyacrylamide gel (37.5:1, acrylamide/bisacrylamide) with a denaturing gradient of 40-60\%, where $100 \%$ denaturant contains $7 \mathrm{M}$ urea and $40 \%(v / v)$ formamide. Electrophoresis was conducted at $60{ }^{\circ} \mathrm{C}$, starting at $150 \mathrm{~V}$ for $10 \mathrm{~min}$ and then at $120 \mathrm{~V}$ for $6 \mathrm{~h}$. The gel was then stained for $30 \mathrm{~min}$ in SYBR green gold nucleic acid gel stain $(1: 10,000)$ and photographed with a GBOX/ HR-E-M (Gene Company Limited, Syngene, UK).

\subsection{Statistical analyses}

The $\mathrm{CH}_{4}$ consumption was plotted using SigmaPlot software (version 10.0). Statistical and correlation analyses were carried out using SPSS software (version 15.0). Oneway ANOVA was used to determine significant differences in potential $\mathrm{CH}_{4}$ oxidation rates and pmoA gene copy numbers among the seven treatments at the $P<0.05$ level.

\section{Results and discussion}

A clear reduction in head-space $\mathrm{CH}_{4}$ concentration was found in the treatments containing soil during the 2-week incubation (Fig. 1). Overall, $\mathrm{CH}_{4}$ was consumed faster in the controls than in the nutrient amendments irrespective of $\mathrm{N}$, $\mathrm{P}$, and $\mathrm{K}$. More $\mathrm{CH}_{4}(83.6 \%)$ was oxidized in the controls and the $\mathrm{NaH}_{2} \mathrm{PO}_{4}$ treatment $(82.9 \%)$ than in any of the other treatments (5.4-74.6\%). The highest methane oxidation rate (MOR) was found in the control, followed by the treatments of $\mathrm{NaH}_{2} \mathrm{PO}_{4}$ and $\mathrm{KH}_{2} \mathrm{PO}_{4}$ during the first $144 \mathrm{~h}$. Then, the MORs in all of the treatments decreased (Fig. 2), although the MORs in the treatments of $\left(\mathrm{NH}_{4}\right)_{2} \mathrm{SO}_{4}$ and urea increased gradually during the 96th to 144th hour (see Fig. 2). Overall, the addition of $\mathrm{N}, \mathrm{P}$, and $\mathrm{K}$ inhibited the potential $\mathrm{CH}_{4}$ oxidation activity to different extents (Fig. S1, Electronic supplementary material).

\subsection{Effect of nitrogen}

For the $\mathrm{N}$ treatments, a significant inhibition of $\mathrm{CH}_{4}$ consumption in acidic rice field soil was observed in the two $\mathrm{N}$ 

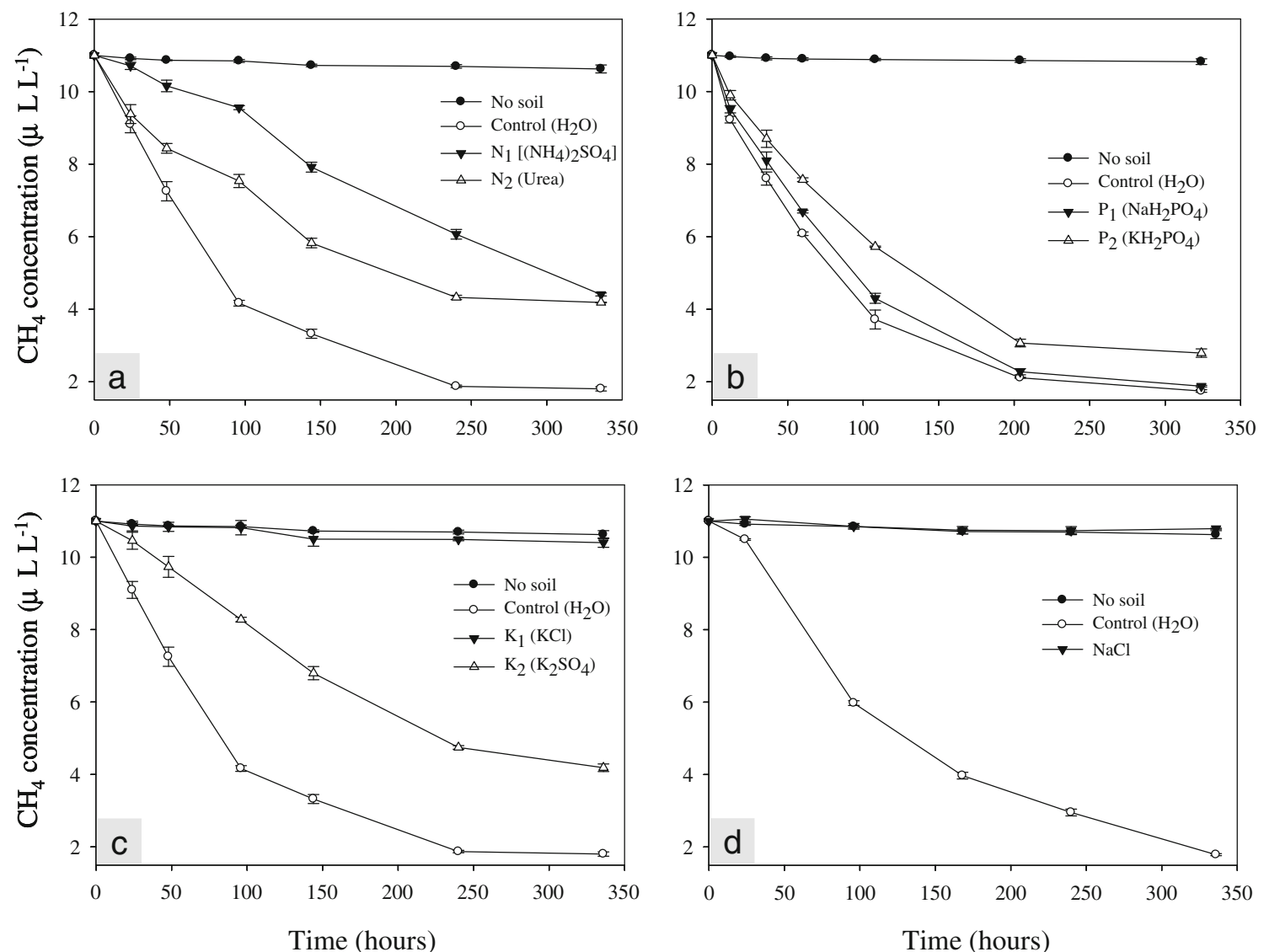

Fig. 1 Effects of the addition of $\mathrm{N}(\mathbf{a}), \mathrm{P}(\mathbf{b}), \mathrm{K}(\mathbf{c})$, and $\mathrm{NaCl}(\mathbf{d})$ on $\mathrm{CH}_{4}$ consumption in a Chinese paddy soil

treatments, $\left(\mathrm{NH}_{4}\right)_{2} \mathrm{SO}_{4}$ and urea. Similarly, an immediate reduction in $\mathrm{CH}_{4}$ oxidation rate of acidic grassland soil by adding $\left(\mathrm{NH}_{4}\right)_{2} \mathrm{SO}_{4}$ was reported previously (Tlustos et al. 1998). $\mathrm{N}$ is typically considered an inhibiting factor of $\mathrm{CH}_{4}$ consumption in soils (Bodelier and Laanbroek 2004; Aronson and Helliker 2010). The competitive inhibitor of MMO and the toxicity of intermediates and end products (i.e., hydroxylamine and nitrite) were together attributed to decreased $\mathrm{CH}_{4}$ oxidation activity (Schnell and King 1995; Hütsch 2001). However, Yang et al. (2011) reported that an appropriate amount of $\mathrm{NH}_{4}{ }^{+}$addition can enhance the $\mathrm{CH}_{4}$ oxidation in the landfill cover soil due to the $\mathrm{NH}_{4}{ }^{+} / \mathrm{CH}_{4}$ ratio $(<0.1)$. Apparently, much higher $\mathrm{NH}_{4}{ }^{+} / \mathrm{CH}_{4}$ ratio (about 760) may result in the inhibition of $\mathrm{CH}_{4}$ oxidation
Fig. 2 Methane oxidation rates (MORs) during the incubation with $\mathrm{N}, \mathrm{P}$, and $\mathrm{K}$ amendments in a Chinese paddy soil

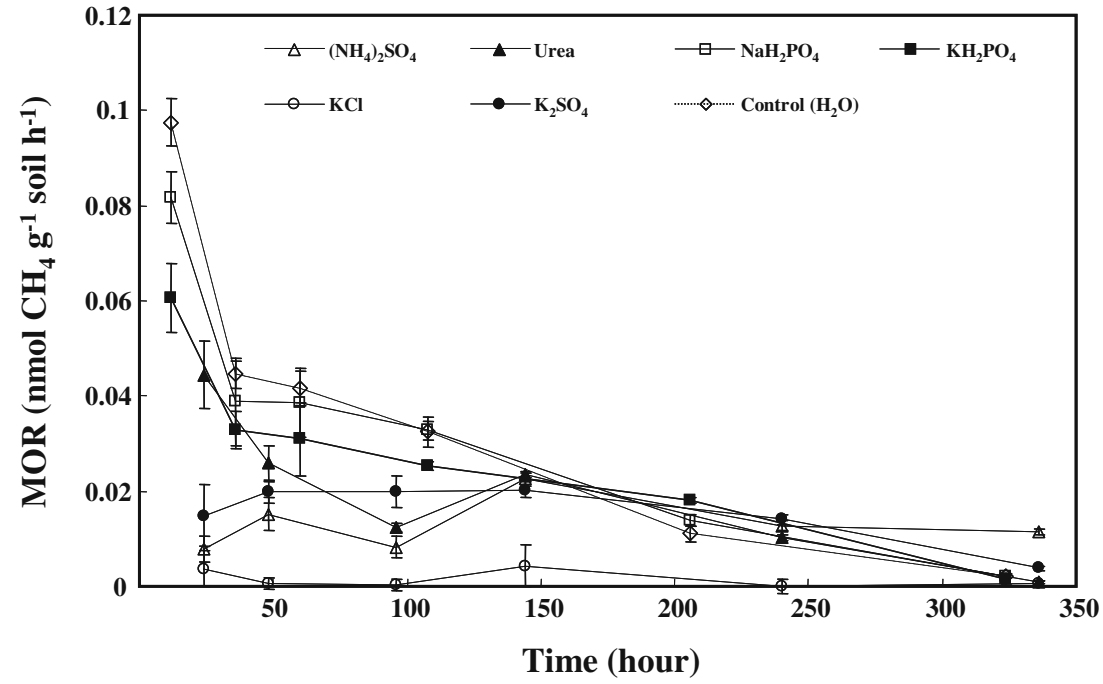


in this study. In addition, compared with the urea treatment, $\left(\mathrm{NH}_{4}\right)_{2} \mathrm{SO}_{4}$ showed stronger inhibition of $\mathrm{CH}_{4}$ oxidation. Similarly, in the rice microcosm, the $\mathrm{CH}_{4}$ oxidation rates were much lower in the $\mathrm{NH}_{4}{ }^{+}$than that in the urea treatment (Shrestha et al. 2010). Collectively, our results indicated that the additions of $\mathrm{N}$ fertilizers inhibited $\mathrm{CH}_{4}$ consumption in acidic rice soil.

\subsection{Effect of phosphorus}

As a major limiting nutrient for plant growth, $\mathrm{P}$ fertilizers are used in intensive agricultural systems to overcome soil $\mathrm{P}$ deficiency and thus achieve higher global food production (Richardson et al. 2011). In the current study, the amendments of $\mathrm{P}$ also negatively affected $\mathrm{CH}_{4}$ oxidation, although the inhibited strength was lower than the $\mathrm{N}$ amendments caused. This result differs from the study by Conrad and Klose (2005), in which P fertilization stimulated the potential methanotrophic activity in the rhizosphere. Given that the effects of $\mathrm{P}$ application on lower $\mathrm{CH}_{4}$ emission in paddy soil were potentially ascribed to plants and/or rhizosphere (Lu et al. 1999; Rath et al. 2005), however, P additions negatively affecting $\mathrm{CH}_{4}$ oxidation in this study could be interpreted as follows. Without planting rice in our incubation experiment, we cannot detect the effect of the rhizosphere on $\mathrm{P}$ assimilation and the subsequent stimulation of $\mathrm{CH}_{4}$ consumption because the rhizosphere induces a spatial pattern in the distribution of methanotrophs and is a potential microsite of intense $\mathrm{CH}_{4}$ oxidation (Dubey and Singh 2000).

\subsection{Effect of potassium}

Approximately $57 \%$ decrease in $\mathrm{CH}_{4}$ occurred before $240 \mathrm{~h}$ of incubation in the $\mathrm{K}_{2} \mathrm{SO}_{4}$ treatment, whereas a small amount of $\mathrm{CH}_{4}\left(0.6 \mu \mathrm{LL}^{-1}\right)$ was oxidized until the end of incubation. However, nearly no change in $\mathrm{CH}_{4}$ concentration was found in the $\mathrm{KCl}$ treatment. Compared with the control, the applications of $\mathrm{K}$ showed inhibitory effect on $\mathrm{CH}_{4}$ oxidation. In a field study, Conrad and Klose (2005) pointed out that the net effect of potassium phosphate on stimulated $\mathrm{CH}_{4}$ emission is mainly from $\mathrm{CH}_{4}$ production and ventilation rather than $\mathrm{CH}_{4}$ oxidation. However, another field study found that $\mathrm{K}$ amendment effectively reduces $\mathrm{CH}_{4}$ emission from flooded soil partly by stimulating the methanotrophic bacterial population (Babu et al. 2006). The difference between these field studies and the current results possibly resulted from the consideration on the function of plant and its rhizosphere effect (Lee et al. 2011). Another possible explanation for this discrepancy could be that the soil water conditions (e.g., flood or drainage) in the field is distinctly different from the soil incubation conditions in the laboratory because increased $\mathrm{CH}_{4}$ oxidation activity was recently demonstrated from continuous flooding to drainage (Ma and $\mathrm{Lu}$ 2011).

\subsection{Effect of chloride}

Interestingly, $\mathrm{CH}_{4}$ consumption was completely inhibited with the addition of $\mathrm{KCl}$. Given that the same $\mathrm{K}$ concentrations were applied in both $\mathrm{K}_{2} \mathrm{SO}_{4}$ and $\mathrm{KCl}$ treatments, an additional incubation experiment was then conducted to verify the effect of $\mathrm{Cl}^{-}$. As predicted, similar result was observed when adding the same concentration of chloride as $\mathrm{NaCl}$ (see Fig. 1). We thus suggest that $\mathrm{Cl}^{-}$inhibited microbial $\mathrm{CH}_{4}$ oxidation during soil incubation. The toxicity of chemical (e.g., halogenated hydrocarbons) on methanotrophs expressing particulate MMO (pMMO) was also examined previously (Han et al. 1999). Additionally, $\mathrm{CH}_{4}$ oxidation could also be inhibited by organic acids and ethanol either through organic compound toxicity or their preferred utilization (Wieczorek et al. 2011). The current results suggest that the main microbial $\mathrm{CH}_{4}$ oxidation was inhibited by $\mathrm{Cl}^{-}$toxicity. However, the methanotrophic community composition would change; some methanotrophs would adapt to the $\mathrm{Cl}^{-}$stress and become as dominant groups. This could be interpreted that different groups have different physiological responses and environmental adaptations to chemicals (Nyerges and Stein 2009).

Indeed, the community structure of methanotrophs was changed under $\mathrm{KCl}$ amendment, as well as other treatments (Fig. S2, Electronic supplementary material), as indicated by specific DGGE bands (i.e., marked from B-1 to B-10), which would be immediately induced by the $\mathrm{N}, \mathrm{P}, \mathrm{K}$, and $\mathrm{Cl}^{-}$amendments. Cluster analyses also showed that the differences in methanotrophic community patterns resulted from the nutrient addition treatments because the changes could be distinguished between treatments (Fig. S3, Electronic supplementary material). However, we cannot identify which methanotroph(s) changed during the treatments because the subsequent DGGE sequencing experiments failed.

\subsection{Methanotrophic abundance under N, P, and K amendments}

In the current study, real-time PCR was used to quantify the methanotrophic pmoA gene copies in the soil samples collected after a 2-week incubation. As shown in Fig. 3, the highest abundance of methanotrophs was found in the $\mathrm{KCl}$ treatment $\left(8.9 \times 10^{7}\right.$ copies per gram of soil), followed by $\mathrm{K}_{2} \mathrm{SO}_{4}\left(7.6 \times 10^{7}\right), \mathrm{NaH}_{2} \mathrm{PO}_{4}\left(6.0 \times 10^{7}\right)$, and $\mathrm{KH}_{2} \mathrm{PO}_{4}$ $\left.5.4 \times 10^{7}\right)$ treatments. The methanotroph abundance found in all four treatments was significantly higher than that in the control $\left(2.8 \times 10^{7}\right)$. Firstly, no significant difference was observed between the two $\mathrm{N}$ treatments $\left[\left(\mathrm{NH}_{4}\right)_{2} \mathrm{SO}_{4}\right.$ and urea; 
Fig. 3 Quantification of methanotrophic pmoA gene copy numbers in a Chinese paddy soil under different nutrient treatments. The different letters above the bars indicate significant differences among treatments at $P<0.05$

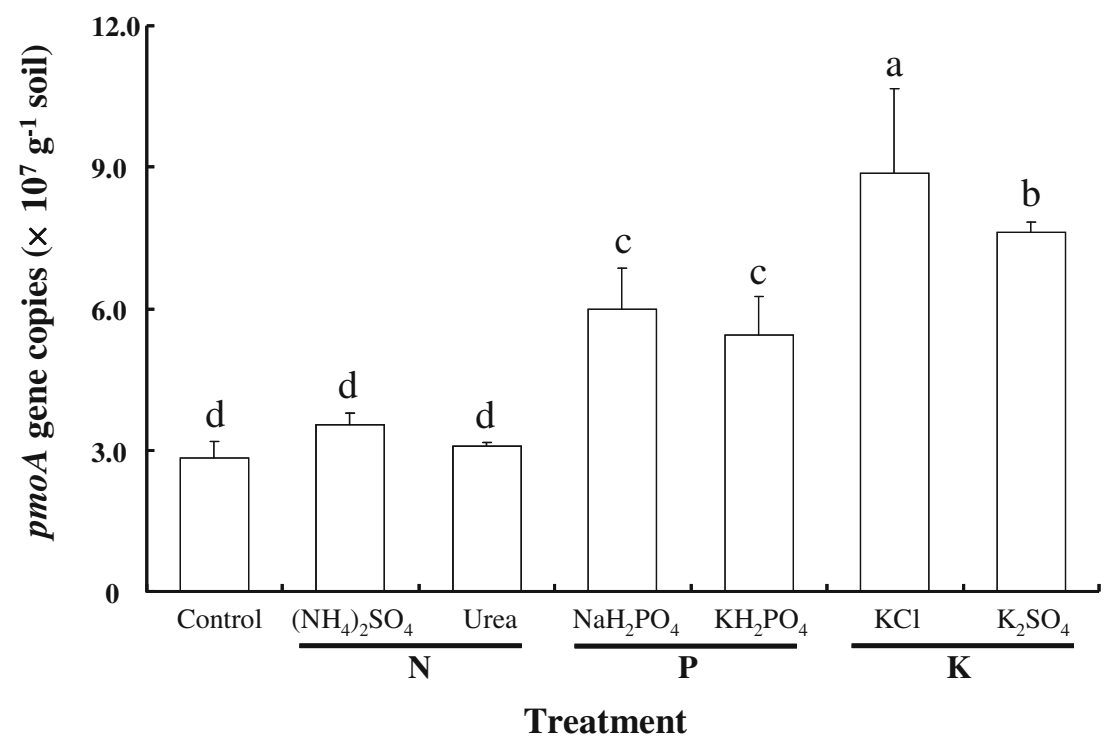

$3.5 \times 10^{7}$ and $3.1 \times 10^{7}$, respectively] and the control. This result is in agreement with another report, which demonstrated that methanotroph abundance was not affected by $\mathrm{N}$ application (animal urine) in six grazed grassland soils (Di et al. 2011). Given that the $\mathrm{CH}_{4}$ oxidation in the $\mathrm{N}$ treatments differed from the control, the results could be explained based on physiological responses, and perhaps environmental adaptations, of methanotrophs, which may have N-specific species (Nyerges and Stein 2009).

Moreover, in contrast to a previous study, which showed that $\mathrm{P}$ was not a key factor controlling the abundance of methanotrophs in paddy soil under long-term fertilization regimes (Zheng et al. 2008), the P treatments applied in the current study resulted in clearly enhanced methanotrophic abundance than the control. It is possible that the effect of $\mathrm{P}$ amendments on the growth or metabolism of methanotrophs was more direct and intensive during the short-term incubation process than their long-term effects in the field plots. However, further research is needed to clarify the short-term stimulation of methanotrophs with $\mathrm{P}$ addition.

Fig. 4 Relationships between methane oxidation activities and methanotrophic pmoA gene copy numbers in a 2 -week incubation experiment with different $\mathrm{N}, \mathrm{P}$, and $\mathrm{K}$ amendments

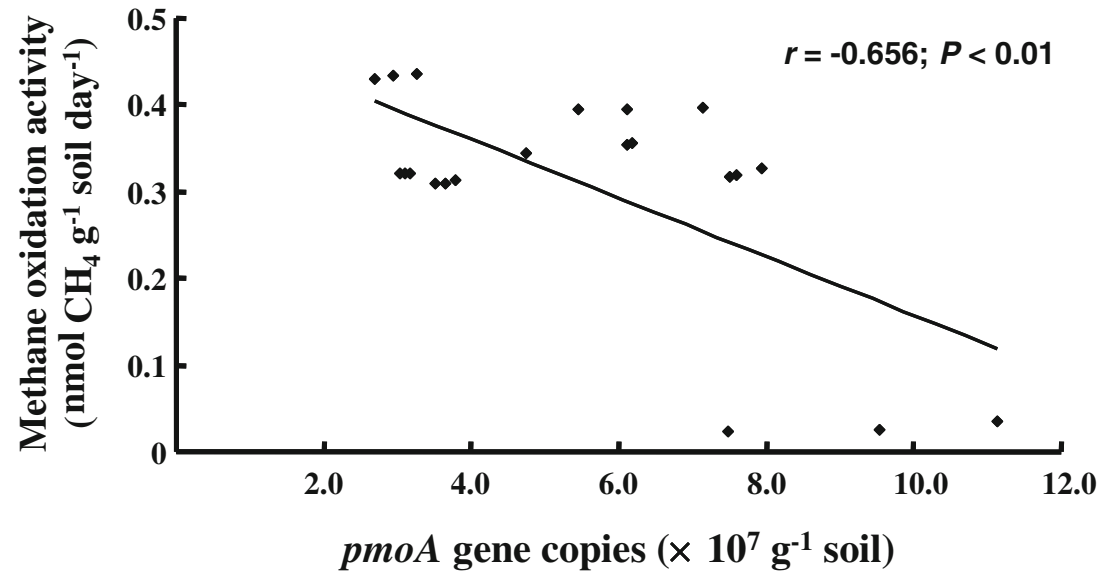

pmoA gene copies $\left(\times 10^{7} \mathrm{~g}^{-1}\right.$ soil $)$
Unexpectedly, significantly higher abundances were detected in the $\mathrm{KCl}$ and $\mathrm{K}_{2} \mathrm{SO}_{4}$ treatments than those in the control. This result was consistent with another study, in which $\mathrm{K}$ fertilizer application seemed to lead to increased methanotrophic abundance in paddy field soil (Zheng et al. 2008). Particularly in the present study, a negative correlation was found between methanotrophic activity and methanotroph abundance $(n=21, P<0.01$, Fig. 4). It was likely that acute chemical-induced stresses changed the ratio of type I to type II methanotrophs and thus resulted in converse shifts in activities and abundance. Future studies are necessary to determine how type I and II methanotrophs adapted to the immediate nutrient and/or chemical stresses. Hence, we suggest that methanotrophic activity cannot be solely inferred through the gene copy numbers of methanotrophs, especially in the short-term simulation experiments. Investigating the size and diversity of the methanotrophic community is not enough to evaluate the soil $\mathrm{CH}_{4}$ sink accurately. The overall $\mathrm{CH}_{4}$ oxidation activity should be taken into consideration. 


\section{Conclusions}

In the present study, we compared the immediate effects of $\mathrm{N}$, $\mathrm{P}$, and $\mathrm{K}$ on the $\mathrm{CH}_{4}$ oxidation and methanotrophic community structure in a Chinese paddy soil through the short-term incubation experiment without planting. N, P, and $\mathrm{K}$ amendments clearly reduced the $\mathrm{CH}_{4}$ oxidation activities. Compared with $\mathrm{N}$ and $\mathrm{K}$, the $\mathrm{P}$ treatments showed a relatively weak inhibitory effect on the $\mathrm{CH}_{4}$ oxidation. In addition, the $\mathrm{P}$ and $\mathrm{K}$ treatments significantly increase methanotrophic abundance, but the $\mathrm{N}$ treatment minimally affected the methanotrophic population size. We further found that $\mathrm{CH}_{4}$ consumption could be completely inhibited by $\mathrm{Cl}^{-}$toxicity. This study revealed that the fertilization could cause immediately negative effects on $\mathrm{CH}_{4}$ consumption and thus potentially enhanced the $\mathrm{CH}_{4}$ emission from paddy soil. Given the same fertilization level, we suggest that increasing the times of fertilization and decreasing the amounts of fertilizers might avoid the acutely negative effect on the $\mathrm{CH}_{4}$ oxidation activity. Additionally, as the current results imply, caution should also be exercised in the application of $\mathrm{KCl}$ fertilizer in agricultural systems to control the increase in $\mathrm{CH}_{4}$ emission from the rice field.

Acknowledgments We thank two anonymous reviewers for their valuable comments on previous versions of the manuscript. This study was supported by grants from the Ministry of Sciences and Technology of China (no. 2012CB956300), the Natural Science Foundation of China (no. 41001149), and the Chinese Academy of Sciences (no. KZCX2-YW-JC401).

\section{References}

Aronson EL, Helliker BR (2010) Methane flux in non-wetland soils in response to nitrogen addition: a meta-analysis. Ecology 91:32423251

Babu YJ, Nayak DR, Adhya TK (2006) Potassium application reduces methane emission from a flooded field planted to rice. Biol Fertil Soils 42:532-541

Bodelier PLE (2011) Interactions between nitrogenous fertilizers and methane cycling in wetland and upland soils. Curr Opin Environ Sustain 3:379-388

Bodelier PLE, Laanbroek HJ (2004) Nitrogen as a regulatory factor of methane oxidation in soils and sediments. FEMS Microbiol Ecol 47:265-277

Bodelier PLE, Roslev P, Henckel T, Frenzel P (2000) Stimulation by ammonium-based fertilizers of methane oxidation in soil around rice roots. Nature 403:421-424

Börjesson G, Sundh I, Tunlid A, Frostegard A, Svensson BH (1998) Microbial oxidation of $\mathrm{CH}_{4}$ at high partial pressures in an organic landfill cover soil under different moisture regimes. FEMS Microbiol Ecol 26:207-217

Conrad R, Donald LS (2007) Microbial ecology of methanogens and methanotrophs. Advances in agronomy. Academic, New York, pp $1-63$

Conrad R, Klose M (2005) Effect of potassium phosphate fertilization on production and emission of methane and its ${ }^{13} \mathrm{C}$-stable isotope composition. Soil Biol Biochem 37:2099-2108
Costello AM, Lidstrom ME (1999) Molecular characterization of functional and phylogenetic genes from natural populations of methanotrophs in lake sediments. Appl Environ Microbiol 65:5066-5074

Dan JG, Krüger M, Frenzel P, Conrad R (2001) Effect of a late season urea fertilization on methane emission from a rice field in Italy. Agric Ecosyst Environ 83:191-199

Di HJ, Cameron KC, Shen JP, Winefield CS, O'Callaghan M, Bowatte S, He JZ (2011) Methanotroph abundance not affected by applications of animal urine and a nitrification inhibitor, dicyandiamide, in six grazed grassland soils. J Soils Sediments 11:432-439

Dubey SK, Singh JS (2000) Spatio-temporal variation and effect of urea fertilization on methanotrophs in a tropical dryland rice field. Soil Biol Biochem 32:521-526

Dumont MG, Radajewski SM, Miguez CB, McDonald IR, Murrell JC (2006) Identification of a complete methane monooxygenase operon from soil by combining stable isotope probing and metagenomic analysis. Environ Microbiol 8:1240-1250

Dunfield PF, Topp E, Archambault C, Knowles R (1995) Effect of nitrogen fertilizers and moisture content on $\mathrm{CH}_{4}$ and $\mathrm{N}_{2} \mathrm{O}$ fluxes in a humisol: measurements in the field and intact soil cores. Biogeochemistry 29:199-222

Gulledge J, Hrywna Y, Cavanaugh C, Steudler PA (2004) Effects of long-term nitrogen fertilization on the uptake kinetics of atmospheric methane in temperate forest soils. FEMS Microbiol Ecol 49:389-400

Han JI, Lontoh S, Semrau JD (1999) Degradation of chlorinated and brominated hydrocarbons by Methylomicrobium album BG8. Arch Microbiol 172:393-400

Hanson RS, Hanson TE (1996) Methanotrophic bacteria. Microbiol Rev 60:439-471

He JZ, Zheng Y, Chen CR, He YQ, Zhang LM (2008) Microbial composition and diversity of an upland red soil under long-term fertilization treatments as revealed by culture-dependent and culture-independent approaches. J Soils Sediments 8:349-358

Holmes AJ, Roslev P, McDonald IR, Iversen N, Henriksen K, Murrell JC (1999) Characterization of methanotrophic bacterial populations in soils showing atmospheric methane uptake. Appl Environ Microbiol 65:3312-3318

Horz HP, Rich V, Avrahami S, Bohannan BJM (2005) Methaneoxidizing bacteria in a California upland grassland soil: diversity and response to simulated global change. Appl Environ Microbiol 71:2642-2652

Hütsch BW (2001) Methane oxidation in non-flooded soils as affected by crop production-invited paper. Eur J Agron 14:237-260

Hütsch BW, Webster CP, Powlson DS (1994) Methane oxidation in soil as affected by land use, soil $\mathrm{pH}$ and $\mathrm{N}$ fertilization. Soil Biol Biochem 26:1613-1622

IPCC (2007) Summary for policymakers. Climate change 2007: the physical science basis. In: Solomon S, Qin D, Manning M, Chen Z, Marquis M, Averyt KB, Tignor M, Miller HL (eds) Contribution of Working Group I to the Fourth Assessment Report of the Intergovernmental Panel on Climate Change. Cambridge University Press, Cambridge, pp 539-543

Jang I, Lee S, Zoh K-D, Kang H (2011) Methane concentrations and methanotrophic community structure influence the response of soil methane oxidation to nitrogen content in a temperate forest. Soil Biol Biochem 43:620-627

King GM (1997) Responses of atmospheric methane consumption by soils to global climate change. Glob Change Biol 3:351-362

Knief C, Lipski A, Dunfield PF (2003) Diversity and activity of methanotrophic bacteria in different upland soils. Appl Environ Microbiol 69:6703-6714

Kolb S (2009) The quest for atmospheric methane oxidizers in forest soils. Environ Microbiol Rep 1:336-346

Le Mer J, Roger P (2001) Production, oxidation, emission and consumption of methane by soils: a review. Eur J Soil Biol 37:25-50 
Lee SY, Lee SH, Jang JK, Cho KS (2011) Comparison of methanotrophic community and methane oxidation between rhizospheric and non-rhizospheric soils. Geomicrobiol J 28:676-685

Liu L, Gundersenb P, Zhang T, Mo JM (2012) Effects of phosphorus addition on soil microbial biomass and community composition in three forest types in tropical China. Soil Biol Biochem 44:31-38

Lu Y, Wassmann R, Neue HU, Huang C (1999) Impact of phosphorus supply on root exudation, aerenchyma formation and methane emission of rice plants. Biogeochemistry 47:203-218

Lü F, He PJ, Guo M, Yang N, Shao LM (2012) Ammonium-dependent regulation of aerobic methane-consuming bacteria in landfill cover soil by leachate irrigation. J Environ Sci 24:711-719

Ma K, Lu YH (2011) Regulation of microbial methane production and oxidation by intermittent drainage in rice field soil. FEMS Microbiol Ecol 75:446-456

Menyailo OV, Hungate BA, Abraham WR, Conrad R (2008) Changing land use reduces soil $\mathrm{CH}_{4}$ uptake by altering biomass and activity but not composition of high-affinity methanotrophs. Glob Change Biol 14:2405-2419

Mohanty SR, Bodelier PLE, Conrad R (2007) Effect of temperature on composition of the methanotrophic community in rice field and forest soil. FEMS Microbiol Ecol 62:24-31

Nyerges G, Stein LY (2009) Ammonia cometabolism and product inhibition vary considerably among species of methanotrophic bacteria. FEMS Microbiol Lett 297:131-136

Rath AK, Ramakrishnan B, Rao VR, Sethunathan N (2005) Effects of rice-straw and phosphorus application on production and emission of methane from tropical rice soil. J Plant Nutr Soil Sci 168:248-254

Reay DS, Nedwell DB (2004) Methane oxidation in temperate soils: effects of inorganic N. Soil Biol Biochem 36:2059-2065

Richardson AE, Lynch JP, Ryan PR, Delhaize E, Smith FA, Smith SE, Harvey PR, Ryan MH, Veneklaas EJ, Lambers H, Oberson A, Culvenor RA, Simpson RJ (2011) Plant and microbial strategies to improve the phosphorus efficiency of agriculture. Plant Soil 349:121-156

Schimel J (2000) Global change: rice, microbes and methane. Nature 403:375-377

Schnell S, King GM (1995) Mechanistic analysis of ammonium inhibition of atmospheric methane consumption in forest soil. Appl Environ Microbiol 60:3514-3521

Seghers D, Top EM, Reheul D, Bulcke R, Boeckx P, Verstraete W, Siciliano SD (2003) Long-term effects of mineral versus organic fertilizers on activity and structure of the methanotrophic community in agricultural soils. Environ Microbiol 5:867-877

Seghers D, Siciliano SD, Top EM, Verstraete W (2005) Combined effect of fertilizer and herbicide applications on the abundance, community structure and performance of the soil methanotrophic community. Soil Biol Biochem 37:187-193
Semrau JD (2011) Current knowledge of microbial community structures in landfills and its cover soils. Appl Microbiol Biotechnol 89:961-969

Shrestha M, Shrestha PM, Frenzel P, Conrad R (2010) Effect of nitrogen fertilization on methane oxidation, abundance, community structure, and gene expression of methanotrophs in the rice rhizosphere. ISME J 4:1545-1556

Singh BK, Bardgett RD, Smith P, Reay DS (2010) Microorganisms and climate change: terrestrial feedbacks and mitigation options. Nat Rev Microbiol 8:779-790

Snyder CS, Bruulsema TW, Jensen TL, Fixen PE (2009) Review of greenhouse gas emissions from crop production systems and fertilizer management effects. Agric Ecosyst Environ 133:247266

Steudler PA, Bowden RD, Melillo JM, Aber JD (1989) Influence of nitrogen fertilization on methane uptake in temperate forest soils. Nature 341:314-316

Tlustos P, Willison TW, Baker JC, Murphy DV, Pavlikova D, Goulding KWT, Powlson DS (1998) Short-term effects of nitrogen on methane oxidation in soils. Biol Fertil Soils 28:64-70

Wieczorek AS, Drake HL, Kolb S (2011) Organic acids and ethanol inhibit the oxidation of methane by mire methanotrophs. FEMS Microbiol Ecol 77:28-39

Yang N, Lü F, He PJ, Shao LM (2011) Response of methanotrophs and methane oxidation on ammonium application in landfill soils. Appl Microbiol Biotechnol 92:1073-1082

Zhang F, She YH, Zheng Y, Zhou ZF, Kong SQ, Hou DJ (2010) Molecular biologic techniques applied to the microbial prospecting of oil and gas in the Ban 876 gas and oil field in China. Appl Microbiol Biotechnol 86:1183-1194

Zheng Y, Zhang LM, Zheng YM, Di HJ, He JZ (2008) Abundance and community composition of methanotrophs in a Chinese paddy soil under long-term fertilization practices. J Soils Sediments 8:406-414

Zheng Y, Liu XZ, Zhang LM, Zhou ZF, He JZ (2010) Do land utilization patterns affect methanotrophic communities in a Chinese upland red soil? J Environ Sci 22:1936-1943

Zheng Y, Yang W, Sun X, Wang SP, Rui YC, Luo CY, Guo LD (2012) Methanotrophic community structure and activity under warming and grazing of alpine meadow on the Tibetan Plateau. Appl Microbiol Biotechnol 93:2193-2203

Zhou XQ, Wang YF, Huang XZ, Hao YB, Tian JQ, Wang JZ (2008a) Effects of grazing by sheep on the structure of methane-oxidizing bacterial community of steppe soil. Soil Biol Biochem 40:258261

Zhou XQ, Wang YF, Huang XZ, Tian JQ, Hao YB (2008b) Effect of grazing intensities on the activity and community structure of methane-oxidizing bacteria of grassland soil in Inner Mongolia. Nutr Cycl Agroecosyst 80:145-152 